\title{
IT governance and IT application orchestration capability role on organization performance during the COVID-19 pandemic: An intervening of business-IT alignment
}

\author{
Afrizal Tahar ${ }^{1 *}$, Hafiez Sofyani ${ }^{2}$, Detra Putri Kunimasari ${ }^{3}$ \\ ${ }^{1}$ Department of Accounting, Faculty of Economics and Business, Universitas \\ Muhammadiyah Yogyakarta, Bantul, Indonesia \\ ${ }^{2}$ Department of Accounting, Faculty of Economics and Business, Universitas \\ Muhammadiyah Yogyakarta, Bantul, Indonesia \\ ${ }^{3}$ Department of Accounting, Faculty of Economics and Business, Universitas \\ Muhammadiyah Yogyakarta, Bantul, Indonesia \\ *Corresponding Author(s) Email : afrizal@umy.ac.id
}

\section{ABSTRACT}

The COVID-19 pandemic has evolved into a multi-faceted global crisis with massive challenges for any organization around the world. With lockdowns and other social distancing protocols implemented in countries worldwide, economic activities and social interactions become increasingly reliant on technology. This study aimed to examine the intervention role of business-IT alignment on the influence of IT governance (ITG) and IT application orchestration capability (IT-AOC) on organization performances. The educational sector was chosen as an object of study as this sector will experience a decade of radical technology-driven change due to COVID-19's stimulus and there were limited IT-AOC studies that used this sector as a research object. This study use a survey method and purposive sampling with a total classified sample of 55 higher education institutions (HEIs) and 110 respondents involved represent the samples. Data analysis was conducted using a Variance-Based Structural Equation Modeling (VB-SEM) approach of Partial Least Square (PLS) technique. The results suggest that both ITG and IT-AOC have a positive effect on organization performances. Moreover, this study proved that businessIT alignment can intervene the influence of ITG and ITAOC on organization performances.

Keywords: IT Governance; IT Orchestration Capability;

Strategic Alignment; Performances; Education Sector; COVID-19
JEL Code:

D33, G30, L26, O33

DOI:

10.31106/jema.v18i1.9311

Article History:

Received 2020/12/28

Reviewed 2021/01/31

Revised 2021/03/06

Accepted 2021/03/13

Licensed:

CC-BY 
IT governance and IT application orchestration capability role on organization performance during the COVID-19 pandemic: An intervening of business-IT alignment by Afrizal Tahar, Hafiez Sofyani,

\section{Introduction}

Detra Putri Kunimasari

The novel coronavirus disease (COVID-19), which was first reported in Wuhan, China, at the end of December 2019, has spread rapidly worldwide, putting billions of people into lockdown. The coronavirus outbreak has been declared a pandemic by the World Health Organization (WHO). The COVID-19's spread had a significant effect on several sectors, including the educational sector. Abidah et al. (2020) added that many countries, including Indonesia, have implemented policies that dismissing all educational activities such as seminars, conferences, athletics, and other activities due to rising concern about the current COVID-19 pandemic. With all government policies and protocols to reduce the spread of the COVID-19, teaching and learning (T\&L) activities are becoming increasingly reliant on technology. At higher education institutions (HEIs), the way of T\&L has been drastically reformed from primarily face-to-face or blended learning to a remote virtual classroom due to the situation of COVID-19. These challenging situations become more complicated than it seems as not all HEIs around the world have had a proper technology infrastructure, support system, and experiences in conducting online learning (Means et al., 2014).

Furthermore, Dodd (2020) added that with the ubiquity of the COVID-19, Australian HEIs have depleted a huge amount of financial resources as their international student revenues have been undermined. Not only affected on T\&L delivery methods and business model. The impact of COVID-19 has also been experienced by universities, business schools, and academicians with workload intensification to adjust the new balance between teaching and research to maintain its quality performance (Brammer \& Clark, 2020). Therefore, any such rapid and radical change and measures need to be managed to ensure and maintain the business model's relevancy and quality performance of HEIs. Weill \& Ross (2004), Kitsios (2017), Queiroz et al. (2018), Oehlhorn et al. (2020) proposed information technology (IT) governance, IT application orchestration capability (IT-AOC), and business-IT alignment as a critical predictor of organization performance especially during the crisis period.

De Haes \& Van Grembergen (2005) defined IT governance as the organizational capacity exercised by the board, executive, and the management to control the formulation and implementation of strategies. The issue of IT governance arises from the huge IT investments made by organizations that have not directly affected the expected results (Ali \& Green, 2005). With effective IT governance, the effectiveness of IT investment to contribute to the superior competitive advantages (Lunardi et al., 2014; Sofyani et al., 2020) and performances (Lazic, 2011; Liang et al., 2011) remain manageable. Furthermore, Queiroz et 
al. (2018) stated that IT-AOC could positively affect better organizational performance. It was also reported that companies with IT-AOC capabilities develop and update a portfolio of IT applications used to support various organizational operational processes. Finally, Seman \& Salim (2013) concluded that business-IT alignment is an important aspect that improves organizational performance as the more aligned the investment of IT with a business purpose, the easiest of organization members to achieve their target performance.

Nowadays, studies related to organization performance determinants, particularly in the educational sector during pandemic COVID-19, are still scarce. Therefore, this study aims to examine the effect of IT governance and IT-AOC on organization performances and test the role of business-IT alignment as intervening. The framework of this study is a development Queiroz et al., (2018) model, which examines the impact of IT-AOC with the agility process on companies' performance in America, Australia, and Germany. They concluded that ITAOC affects process agility and improves organizational performance. Furthermore, they suggest further study to develop IT-AOC measures with other issues such as application ownership, governance, and control. Therefore, this study adds IT governance variables and the intervening role of the business-IT alignment variable. The educational sector (HEI) was chosen as an object of study as this sector will experience a decade of radical technologydriven change due to COVID-19's stimulus and there were limited studies that used this sector in IT governance and IT-AOC studies.

\section{Literature Review}

\section{Performance Quality}

Baker \& Crompton (2000) defined performance quality as a conceptual measurement of a provider's output, whereas a level of satisfaction of product outcome. Performance quality also indicates the perceived superiority and excellence of the product's performance compared with other alternatives (Mugge \& Schoormans, 2012). Parker (2020) added that performance is often declared as quality, although in fact, a term of quality is more represents a code for quantity, speed, growth, cost management, and profits. For the higher education sector, each performance (key performance index-KPI) measurement is often reported on each HEI website as a strategy for attracting and maintaining stakeholder support. Parker (2020) stated that HEI KPIs pervasiveness scorecard (which ranged from 35 until 41 KPI's) needs to be monitored periodically. He added that reputation, learning and teaching, research performance, community engagement, market share, student numbers, HEI status rankings, number of publications, facilities expenditure, and capital fundraising are general examples 
IT governance and IT application orchestration capability role on organization performance during the COVID-19 pandemic: An intervening of business-IT alignment by Afrizal Tahar, Hafiez Sofyani,

Detra Putri Kunimasari

of HEIs invasiveness KPIs. Kurniasih et al. (2018) also highlighted that many indicators could be used to define HEIs quality. It's challenging to have the same meaning regarding the standard of quality. For example, 4ICU rankings that choose web traffic as the base of a ranking system, QS World that focused on academic and institution reputation, the ratio of international students, the number of citations, the Academic Ranking of World Universities (ARWU) use six indicators including the number of staffs and alumni who won the Nobel Prizes and Fields Medals, the number of citations in Thomson Reuters, the number of articles published in reputable journals as ranking parameters, and the last is, webometrics which is normalized variables into a ratio of 1:1 before combining between activity/presence and visibility/impact of the indicator group, and several other ratings. In the case of Indonesia, the National Accreditation Board for Higher Education (BAN PT) launched nine standards of accreditation which consist of the assessment of vision, mission, objectives, strategic implementation, the quality of general and financial management, the quality of student activities, the quality of human resources, $\mathrm{T} \& \mathrm{~L}$ activities, research, community services, and publications (Hill \& Wie, 2012; Ulum, 2019).

\section{IT Governance}

IT governance plays a significant role in creating value to assist organizations in achieving competitive advantages. According to the resource-based view (RBV) theory, a competitive advantage is achieved by creating valuable, rare, inimitable, and irreplaceable resources (Barney, 2000). IT governance itself was defined by De Haes \& Van Grembergen, (2009) as "the organizational resource to control the formulation and implementation of the IT strategy and ensure that the organization uses appropriate IT resources to serve business strategy." Symosns (2005) added the definition by stated that IT governance is "the process of making decisions about IT investments - how decisions are made, which makes the decisions, who is responsible, and how to measure and monitor the results of decisions." IT governance includes strategies, policies, responsibilities, structures, and processes for using information technology in an organization (Fernández \& Llorens, 2009; Bandiyono \& Muttaqin, 2020). Ali \& Green (2009) and Aasi \& Rusu (2017) added that IT governance in a public organization had led the organization to focus on IT governance outcome of effective use of IT for growth. IT governance could be classified into four dimensions which are IT strategy risk, value delivery, risk management, and performance measurement (Sirisomboonsuk, et al, 2018). Turel et al. (2019), Bianchi et al, (2017), and Sirisomboonsuk 
et al. (2018) found that IT governance could increase financial performances (such as ROA, ROE, and profit margins) and organizational performance.

$\mathrm{H}_{1}$ : $\quad$ IT governance has a positive effect on organization performance.

\section{IT Application Orchestration Capability (IT-AOC)}

IT capability is rooted in the idea of dynamic capability. Sambamurthy \& Zmud (2000) and Rai et al. (2012) define IT capabilities as the combination of IT-based assets, functionalities, and routines used to make a unique source of competitive advantage. Queiroz et al. (2018) broaden the IT capability concept into IT orchestration capability (IT-AOC). Thus, he conceptualized IT-AOC as an organization's ability to renew the IT application portfolio through a process of development, purchase, and replacement. Bharadwaj (2000) added that to achieve optimal performance, organizations should have the ability to update the applications used to support business processes and mobilize and deploy IT-based resources. A firm with IT-AOC possesses the ability to develop IT application portfolios (either incremental or discontinuous) internally. Therefore, due to the complex mechanism, IT-AOC reflects the organization's ownership of valuable, rare, inimitable, and nonsubstitutable resources proposed by Barney (2000) in resource-based view (RBV) theory. Previous studies by Ray et al. (2014), Setia et al. (2013), Arora \& Rahman (2017), Papadopoulos et al. (2017) show that IT capabilities have a positive effect on business performance.

$\mathrm{H}_{2}$ : IT-AOC has a positive effect on organization performance.

\section{The Importance of Business-IT Alignment}

IT strategic alignment can be defined as the extent to which the priorities and objectives of the IT strategy are aligned or converges with the priorities and objectives of business strategy such as reducing cost and increasing revenue (Oh \& Pinsonneault, 2007; Sabherwal \& Chan, 2001). In every organization, the alignment or synchronization of business objectives and IT initiatives portfolio becomes crucial to realize as it can optimize the dynamic of business goals and processes (Primasari, 2020; Ullah \& Lai, 2013). Gerow, et al. (2014) classified that alignment into two categories which are intellectual alignment and operational alignment. While intellectual alignment deals with the alignment of business knowledge and strategic plans (what the organization intends to do), operational alignment reflects the alignment of operational infrastructure and processes strategy (Tallon et al., 2016). Reich \& Benbasat (2000) and Gutierrez et al. (2009) added that the critical success 
IT governance and IT application orchestration capability role on organization performance during the COVID-19 pandemic: An intervening of business-IT alignment by Afrizal Tahar, Hafiez Sofyani,

Detra Putri Kunimasari

factor that will implement IT initiatives success is related to the level of trust IT departments have to promote partnerships between business and IT managers. Moreover, Chan \& Reich (2007) and Tallon \& Pinsonneault (2011) stated that the alignment of business strategy and IT initiatives positively affects organizational performance.

$\mathrm{H}_{3}$ : Business-IT alignment has a positive effect on organization performance.

The intervening role of business-IT alignment is a critical factor in ensuring IT initiatives' successful implementation in numerous studies. Ping-Ju Wu et al. (2015) concluded that the IT governance effect on organizational performance is fully interverned by strategic alignment. Sirisomboonsuk et al. (2018) added that the harmony of IT governance and project governance is positively associated with project performances which means that IT governance will impact excellence performance, especially when strategic alignment is realized. Moreover, Chan \& Reich (2007), Sabherwal \& Chan (2001), and Wade \& Hulland (2004) added that IT capabilities can create the characteristics of valuable, rare, inimitable, and non-substitutable, have a positive effect on business alignment and organizational performance.

$\mathrm{H}_{4 \mathrm{a}}$ : IT governance affects organization performance by positively facilitating business-IT alignment.

$\mathrm{H}_{4 \mathrm{~b}}$ : IT-AOC affects organization performance by positively facilitating business-IT alignment.

\section{Methods}

This study used a survey method with quantitative hypothesis testing and was conducted in Central Java with a total population of 264 HEIs. Central Java was chosen as the study location because it is one of the provinces with decent educational facilities and proper quality. There were five HEIs that have A accreditation by the National Accreditation Board for Higher Education (BAN PT); thus, 84 have B accreditation, 49 have C accreditation, respectively, and the rest of 126 HEIs have not been accredited. Furthermore, the sample was selected using a convenience random sampling technique because all HEIs in Central Java have the same opportunity to be sampled. The respondents were selected using a purposive method, such as people with knowledge of IT implementation and HEI performance. The survey data collection was conducted a five-point Likert scale questionnaire from September $15^{\text {th }}$ until October $21^{\text {st }}, 2020$. Data analysis was performed using a Variance-Based Structural Equation Modeling (VB-SEM) approach of Partial Least Square (PLS) technique. To ensure a high rate of return, questionnaires were distributed in person and online. Due to the 
considerable distance between HEIs and the ongoing COVID-19 pandemic situations, the number of HEIs that can be processed is only 68 with a total of 193 copies of the questionnaire have been distributed to rectors, vice-rectors, deans, vice-deans, and head of departments. The questionnaires returned were 110 from 55 HEIs or 80.88\% (55/68 HEIs), and the online distribution did not receive any response. Even though the response rate is high, this sample size is not ideal when referring to Krejcie \& Morgan, (1970) guidance. However, these numbers and percentages are acceptable when compared to similar surveys with organizations as analysis units. This study has response rates in the 10-20\% range of the minimum sample required (Fowler Jr., 2013) which is higher than that achieved by Alach (2017) who only measured 57 (12\%) out of 471 HEIs in New Zealand, and Bobe \& Kober (2018) who only had a response rate of $28.3 \%$, with 56 usable questionnaires. Therefore, the comparison of those previous studies showed that the response rate of this study is acceptable.

Figure 1. Research Framework

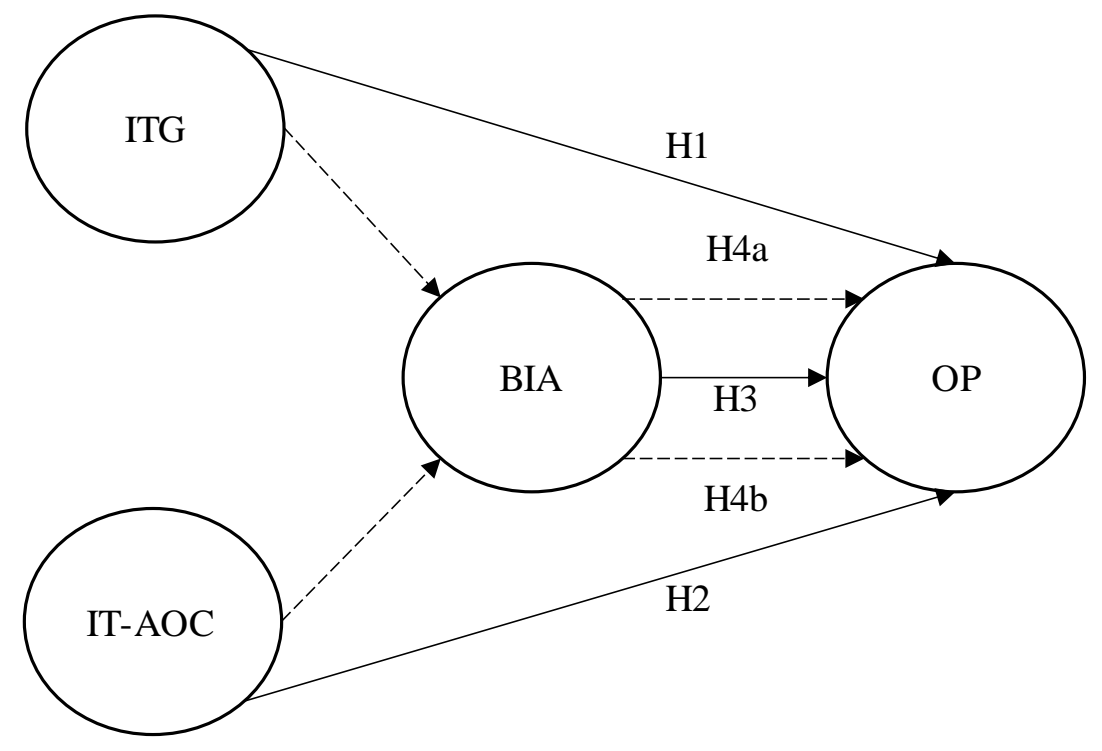

Note: ITG = IT governance; IT-AOC = IT application orchestration capability; BIA = Business-IT Alignment; OP = Organization performance

In this study, IT governance was measured using three items proposed by Ali \& Green (2009) and Aasi \& Rusu (2017). While IT-AOC was designed using three-items of Queiroz et al. (2018), the five-item business-IT alignment was adapted from Gutierrez et al. (2009). The measurement of organizational (HEI) performances was conducted by following the nine standards of the National Accreditation Board for Higher Education (BAN PT), such as the assessment of vision, mission, objectives, strategic implementation, the quality of general and financial management, student activities, human resources, T\&L activities, research, 
IT governance and IT application orchestration capability role on organization performance during the COVID-19 pandemic: An intervening of business-IT alignment by Afrizal Tahar, Hafiez Sofyani,

Detra Putri Kunimasari community services, and publications. All constructs were measured using a five-point Likert where 1 denotes 'Strongly Disagree' and 5 denotes 'Strongly Agree'.

Table 1. Questionnaire Items

\begin{tabular}{|c|c|c|c|}
\hline Variables & Code & Item & Reference \\
\hline \multirow[t]{4}{*}{ ITG } & & $\begin{array}{l}\text { The current individual IT governance within my } \\
\text { organization's... }\end{array}$ & \multirow{4}{*}{$\begin{array}{c}\text { Ali \& Green, } \\
\text { (2009), Aasi \& } \\
\text { Rusu (2017) }\end{array}$} \\
\hline & ITG1 & $\begin{array}{l}\text { Has a positive impact on the overall effectiveness } \\
\text { of the organization }\end{array}$ & \\
\hline & ITG2 & $\begin{array}{l}\text { Has value aid on the overall effectiveness of the } \\
\text { organization. }\end{array}$ & \\
\hline & ITG3 & $\begin{array}{l}\text { Are essential to accomplish the success of the } \\
\text { organization. }\end{array}$ & \\
\hline \multirow[t]{4}{*}{ IT-AOC } & & $\begin{array}{l}\text { Relative to major competitors, my organization's } \\
\text { can quickly... }\end{array}$ & \multirow[t]{4}{*}{$\begin{array}{l}\text { Queiroz et al. } \\
\qquad(2018)\end{array}$} \\
\hline & IT-AOC1 & Develop IT applications internally. & \\
\hline & IT-AOC2 & Purchase valuable IT applications from suppliers. & \\
\hline & IT-AOC3 & Discontinue less-valuable IT applications & \\
\hline \multirow[t]{5}{*}{ BIA } & BIA1 & $\begin{array}{l}\text { Understanding of business strategies by the IT } \\
\text { department. }\end{array}$ & \multirow[t]{5}{*}{$\begin{array}{l}\text { Gutierrez et al. } \\
\qquad(2009)\end{array}$} \\
\hline & BIA2 & $\begin{array}{l}\text { Understanding of IT capabilities by the } \\
\text { organization executives. }\end{array}$ & \\
\hline & BIA3 & $\begin{array}{l}\text { Knowledge sharing between organizational levels } \\
\text { from strategic to operational. }\end{array}$ & \\
\hline & BIA4 & $\begin{array}{l}\text { Conducting regular meetings to discuss IT } \\
\text { priorities, requirements, and implementation. }\end{array}$ & \\
\hline & BIA5 & $\begin{array}{l}\text { Creating a flexible communication environment to } \\
\text { discuss business and IT strategies. }\end{array}$ & \\
\hline \multirow[t]{9}{*}{$\mathrm{OP}$} & OP1 & Our $T \& L$ activities are effective & \multirow{9}{*}{$\begin{array}{l}\text { Hill \& Wie } \\
\text { (2012), } \\
\text { Queiroz et al. } \\
\text { (2018), Ulum } \\
\text { (2019) }\end{array}$} \\
\hline & $\mathrm{OP} 2$ & $\begin{array}{l}\text { Our online T\&L activities running smoothly during } \\
\text { the COVID-19 pandemic }\end{array}$ & \\
\hline & OP3 & Our mentorship program is running as scheduled. & \\
\hline & OP4 & Our journal publications (Sinta) increases. & \\
\hline & OP5 & Our journal publications (Scopus/WOS) increases. & \\
\hline & OP6 & Our community service is running effectively & \\
\hline & OP7 & Our academic service is effective & \\
\hline & OP8 & Our academic service is reliable & \\
\hline & OP9 & Our performances are in-line with our objectives & \\
\hline
\end{tabular}


Before the proposed hypotheses were tested, the validity (convergent and discriminant test) and reliability (Cronbach's Alpha and composite test) measurements need to be done. Table 2 shows the result of the outer loading and AVE test.

Table 2. Outer Loading and AVE Result

\begin{tabular}{|c|c|c|}
\hline Variable/indicator & Outer Loading & AVE \\
\hline ITG & & 0.773 \\
\hline ITG1 & 0.888 & \\
\hline ITG2 & 0.922 & \\
\hline ITG3 & 0.824 & \\
\hline ITAOC & & NA** \\
\hline IT-AOC1 & 0.937 & \\
\hline IT-AOC2 & $0.335^{*}$ & \\
\hline IT-AOC3 & 0.849 & \\
\hline BIA & & 0.686 \\
\hline BIA 1 & 0.828 & \\
\hline BIA 2 & 0.817 & \\
\hline BIA 3 & 0.852 & \\
\hline BIA 4 & 0.787 & \\
\hline BIA 5 & 0.843 & \\
\hline BIA 6 & 0.849 & \\
\hline BIA 7 & 0.819 & \\
\hline $\mathrm{OP}$ & & 0.667 \\
\hline OP1 & 0.843 & \\
\hline $\mathrm{OP} 2$ & 0.849 & \\
\hline OP3 & 0.877 & \\
\hline OP4 & 0.594 & \\
\hline OP5 & $0.391 *$ & \\
\hline OP6 & 0.881 & \\
\hline OP7 & 0.917 & \\
\hline OP8 & 0.927 & \\
\hline OP9 & 0.907 & \\
\hline
\end{tabular}

*) Removed from the model; **) PLS did not calculate AVE scores because IT-AOC is a formative construct 
IT governance and IT application orchestration capability role on organization performance during the COVID-19 pandemic: An intervening of business-IT alignment by Afrizal Tahar, Hafiez Sofyani,

Detra Putri Kunimasari

Based on Table 2, IT-AOC2 needs to be removed from the model as the value of the loading score was less than 0.700 (Ketchen, 2013). Table 2 also shows that all variables with reflective constructs are valid as the value of AVE was higher than 0.500. Thus, the validity measurement of the formative construct which is IT-AOC conducted by using the significance of the outer weight as presented in Table 3.

Table 3. Formative Construct Validity Test Result (IT-AOC)

\begin{tabular}{cccc}
\hline \multirow{2}{*}{ Indicator } & \multicolumn{2}{c}{ Outer Weight } & VIF \\
& t-statistics & p-values & \\
\hline IT-AOC1 & 2.695 & $0.002^{*}$ & 1,719 \\
IT-AOC2 & 0.562 & 0.287 & 1,047 \\
IT-AOC3 & 1.685 & $0.046^{* *}$ & 1,699 \\
\hline
\end{tabular}

*) Significant at alpha 0.01 ;*) Significant at alpha 0.05

Table 3 shows that the outer weight value of IT-AOC2 indicator was not significant. According to Hair et al. (2013), if the item shows insignificant p-values, the researchers need to look at the outer loading value. If the outer loading score was higher than 0.700 means that the item can be preserved. In Table 2, the outer loading column shows that the IT-AOC 2 item is lower than $0.700(0.335)$ so that the item must be deleted while the other two items are retained. Additionally, the VIF scores of all IT-AOC indicators are less than 5. This indicates that there is no multicollinearity indication among indicators (Ketchen, 2013). Furthermore, the discriminant validity test consists of two types of calculations: looking at the AVE root in the Fornell Larcker table on the Path Algorithm and listening to the crossloading table. Table 4 shows the AVE root value of each construct is greater than the correlation value between variables. Thus the discriminant validity has been fulfilled (Ketchen, 2013).

Table 4. Discriminant Validity Test Result (Fornell-Larcker)

\begin{tabular}{lcccc}
\hline Variable & OP & IT-AOC & BIA & ITG \\
\hline OP & $\mathbf{0 . 8 5 6}$ & & & \\
IT-AOC & 0.396 & NA $^{*}$ & & \\
BIA & 0.449 & 0.266 & $\mathbf{0 . 8 2 8}$ & \\
ITG & 0.409 & 0.200 & 0.330 & $\mathbf{0 . 8 7 9}$ \\
\hline
\end{tabular}

*) The score was not calculated by PLS because IT-AOC is a formative construct 
To test the reliability of variables, Hair et al. (2013) argued that the rules of thumb to measure reliability are Cronbach's alpha must be higher than 0.600 and composite reliability must be greater than 0.700 . The reliability was tested to measure the consistency of the study construct. Table 5 shows that all variables in this study are reliable as the value of Cronbach's alpha and composite reliability was higher than 0.600 and 0.700 .

Table 5. Reliability Test Results

\begin{tabular}{lcc}
\hline Variables & Cronbach's Alpha & Composite Reliability \\
\hline ITG & 0.855 & 0.911 \\
IT-AOC & NA* & NA* \\
BIA & 0.924 & 0.939 \\
OP & 0.945 & 0.956 \\
\hline
\end{tabular}

*) The score was not calculated by PLS because IT-AOC is a formative construct

Since the nature of survey data is classified as self-reporting, Podsakoff et al. (2003) argue that there was a potential for common method variance (CMV). CMV occurred when there was a condition where respondents try to give only positive or normative answers (Chang et al., 2010). Tehseen et al. (2017) added that this bias arose when one factor emerged from the factor analysis or one common factor accounted for most of the covariance between measures i.e. more than $50 \%$. Harman's single-factor method results showed a total variance of $75.53 \%$, and the first factor did not account for the majority of the variance (only $40.93 \%$ ). These results confirmed that common-method bias was not a likely threat in this study.

\section{Result and Discussion}

The majority of respondents in this study (Table 6) were head of a department (43.636\%) followed by the rector-vice rector (40\%), and dean-vice dean $(16.363 \%)$. It is noted that about $66.363 \%$ of our respondents have Master Degree as their educational background followed by Doctoral (21.818\%), and Bachelor (11.818\%). Moreover, most of the HEIs in this study were classified with B grades $(69.09 \%)$ by the National Accreditation Board for Higher Education (BAN PT) which means that the majority of HEIs in this study can be classified in a good level of HEIs performance. Finally, in term of HEIs type, the number of private HEIs participation $(87.273 \%$ ) overcome the number of public HEIs participation $(12.727 \%)$. 
IT governance and IT application orchestration capability role on organization performance during the COVID-19 pandemic: An intervening of business-IT alignment by Afrizal Tahar, Hafiez Sofyani,

Table 6. Demographic Profile

\begin{tabular}{|c|c|c|c|}
\hline $\begin{array}{l}\text { Demographic Profile } \\
\text { (HEI/Sample) }\end{array}$ & $\begin{array}{l}\text { Percentage } \\
(\%)\end{array}$ & $\begin{array}{l}\text { Demographic Profile } \\
\text { (Respondent/Unit Sampling) }\end{array}$ & $\begin{array}{l}\text { Percentage } \\
\quad(\%)\end{array}$ \\
\hline Accreditation & & Structural Position : & \\
\hline A & 5.454 & Rector-Vice Rector & 40 \\
\hline B & 69.090 & Dean-Vice Dean & 16.363 \\
\hline $\mathrm{C}$ & 23.636 & Head of Department & 43.636 \\
\hline Type : & & Educational Background & \\
\hline Private & 87.273 & Bachelor & 11.818 \\
\hline \multirow[t]{2}{*}{ Public } & 12.727 & Master & 66.363 \\
\hline & & Doctoral & 21.818 \\
\hline Number of HEI & 55 & Number of respondents & 110 \\
\hline
\end{tabular}

Table 7. Descriptive Statistics

\begin{tabular}{lccccc}
\hline Variable & $\mathbf{N}$ & Minimum & Maximum & Mean & Std. Deviation \\
\hline ITG & 110 & 2.700 & 5 & 4.285 & .6525 \\
IT-AOC & 110 & 2 & 5 & 3.579 & .7360 \\
BIA & 110 & 2.900 & 5 & 4.114 & .5995 \\
\hline
\end{tabular}

Table 8. Hypotheses Testing

\begin{tabular}{lcccc}
\hline Relationships & Original Sample & t-Value & p-Value & Decision \\
\hline ITG $\rightarrow$ OP & 0.259 & 2.357 & $0.009^{*}$ & $\mathrm{H}_{1}$ Supported \\
IT-AOC $\rightarrow$ OP & 0.267 & 2.375 & $0.009^{*}$ & $\mathrm{H}_{2}$ Supported \\
$\mathrm{BIA} \rightarrow$ OP & 0.293 & 2.676 & $0.004^{*}$ & $\mathrm{H}_{3}$ Supported \\
ITG $\rightarrow$ BIA $\rightarrow$ OP & 0.085 & 1.753 & $0.040^{* *}$ & $\mathrm{H}_{4 \mathrm{a}}$ Supported \\
IT-AOC $\rightarrow$ BIA $\rightarrow$ OP & 0.061 & 1.360 & $0.087^{* * *}$ & $\mathrm{H}_{4 \mathrm{~b}}$ Supported \\
\hline
\end{tabular}

*) Significant at alpha $0.01 ; * *)$ Significant at alpha $0.05 ; * * *)$ Significant at alpha 0.10

The descriptive statistics of Table 7 shows that our respondents evaluate the implementation of ITG and IT-AOC in their HEIs on the below scale of 3. According to Alach (2017), while the score of 1 of questionnaire distribution indicates very poor implementation, the score of 5 of questionnaire distribution was classified as very good implementation. Therefore, the minimum value of questionnaire distribution in Table 7 , which is still below 3, shows that there is a HEIs stakeholder in this study that experiences the ineffective process of ITG, the vulnerable orchestration of IT-AOC, and the inefficiency 
of BIA. Moreover, the IT-AOC mean score that is amounted to 3.579 means that there is an issue of IT-AOC actualization in the most of observed HEIs in this study.

Table 8 of the hypotheses testing result revealed that all proposed hypotheses in this study are supported as the p-value of each construct relationship (0.009, 0.009, 0.004, 0.040, 0.087 ) are smaller than $0.010,0.050$, and 0.100 . This study support previous studies by Ray et al. (2014), Setia et al. (2013), Papadopoulos et al. (2017), Arora \& Rahman (2017), Bianchi et al. (2017), Sirisomboonsuk et al. (2018), and Turel et al. (2019) that stated there are positive relationship between IT governance and IT application orchestration capabilities on organizational performance. Therefore, it can be concluded that the more effective IT governance and the more capable and faster the organization to update their IT portfolio internally, the higher the organization performance, in this case, HEI. Although Means et al. (2014) and Dodd (2020) argue that many HEIs have had no proper technology infrastructure due to their financial issues, the challenges of the COVID-19 pandemic was enforcing the HEI management to adjust their technology capabilities quickly. The result of descriptive statistical data in Table 5 shows that the most of respondents in this study are having a positive evaluation in the implementation of IT governance and business-IT alignment in their HEI. However, it should be noted that the implementation of IT-AOC is still not optimal. Shenoy et al. (2020) stated there was a huge resistance in the teaching fraternity to adapt with technology, but due to the recent COVID-19 pandemic situation, broad and hasty adoption of commercial digital learning solutions cannot be avoided. Many HEIs have adapted technology and started taking virtual classes (learning) by using Zoom, Google Hangouts, Skype meet up, Google classrooms, learning management systems (LMS), YouTube, etc. Using those "ready to use" digital learning solutions, the internal (both executive and operational) evaluation about their IT capabilities also increases exponentially. Apart from T\&L activities, improvements in IT governance and updating IT portfolios are also aimed at research, publication, and community service activities. As we found in the field, the direction of research policy began to focus on secondary data, data analysis with more up-to-date software applications, and community service lecturers who shifted to the use of video media and teleconferencing. Workshops, seminars, and conferences that aim to improve publication qualities and quantities are also carried out through teleconferences. Additionally, IT updates in terms of governance and portfolio also penetrate student administration services such as tuition payments, etc. to be more adaptive.

This study also supports Chan \& Reich (2007) and Tallon \& Pinsonneault (2011) conclusion that stated there is a positive relationship between business-IT alignment and 
IT governance and IT application orchestration capability role on organization performance during the COVID-19 pandemic: An intervening of business-IT alignment by Afrizal Tahar, Hafiez Sofyani,

Detra Putri Kunimasari

organizational performance, which means that the more synchronize organization objective with IT strategy, the higher level performances will be achieved. Furthermore, this study also proved the role of business-IT alignment in intervention the effect of IT governance and IT application orchestration capabilities on organizational performance as the conclusion of the previous study by Ping-Ju Wu et al. (2015), Sirisomboonsuk et al. (2018), Turel et al. (2019), Chan \& Reich (2007), Sabherwal \& Chan (2001), and Wade \& Hulland (2004). We argue that the level of effectiveness of IT governance and IT-AOC were increases during pandemic situations as this unprecedented situation has obligated HEIs stakeholder to conduct businessIT alignment activities frequently in order to maintain or even enhances the performances of HEIs. It can be concluded that HEIs that have attention to legitimacy and their main stakeholders should adopt IT that is aligned with their business processes.

Kahli \& Grover (2008) contend that business-IT alignment is one of intervening factors that are considered essential and critical for creating a value chain. From this finding, it can be concluded that's to improve HEIs performance, the alignment between HEIs objective and IT portfolio needs to be accomplished at the first time by creating a regular meeting, sharing knowledge culture, and building freedom of speech environment. This finding successfully advanced the existing IT-AOC model by Queiroz et al. (2018) by significantly proves the intervening role of business-IT alignment and IT governances in affecting organization performances. The results also confirm the RBV theory and intend to broaden the discussion of IT-AOC concept in the educational sector (HEI) as previous related studies only covered manufacturing sectors.

\section{Conclusion and Suggestion}

This study aims to examine and analyze the effect of IT governance and IT-AOC, business-IT alignment on organization (higher education institutions) performances with business-IT alignment role as an intervening variable. This study indicates that IT governance, IT-AOC, and IT business alignment positively affect higher education institutions' (HEI) performances in different levels of significances. Moreover, this study proved that business-IT alignment can intervene the influence of ITG and IT-AOC on HEI performances. These findings suggest that in order to enhances HEI performances subsequently, it is crucial for HEI management to implements IT governance effectively, improves IT-AOC, and strive to achieves business-IT alignment.

Although this study contributes to IT governance, IT-AOC, and business-IT alignment literature regarding their role on educational sector performances during the COVID-19 
pandemic, this study has several limitations that need to be addressed. First, this study was only conducted in HEI that's located in Central Java with a minimal sample. Therefore, this study's results are not strong enough to be generalized to a broader context, for example, Indonesia. Further studies should be conducted at HEIs in other areas. Furthermore, this study only uses a survey as their research method, therefore, how IT governance, IT-AOC, and IT business alignment affect organization performance is not described in detail and in-depth. To address this limitation, further studies need to explore the same topic with a case study approach to discover more prosperous and profound insight.

\section{References}

Aasi, P., \& Rusu, L. (2017). Facing the digitalization challenge: Why organizational culture matters and how it influences it governance performance. Conference: 26th International Conference on Information Systems Development (ISD2017 Cyprus) At: Larnaca, Cyprus.

Abidah, A., Hidaayatullaah, H. N., Simamora, R. M., Fehabutar, D., \& Mutakinati, L. (2020). The impact of covid-19 to indonesian education and its relation to the philosophy of "Merdeka Belajar." Studies in Philosophy of Science and Education, 1(1), 38-49. https://doi.org/10.46627/sipose.v1i1.9

Alach, Z. (2017). The use of performance measurement in universities. International Journal of Public Sector Management, 30(2). Retrieved from http://dx.doi.org/10.1108/IJPSM05-2016-0089

Ali, S., \& Green, P. (2005). Determinants of effective information technology governance. International Journal of Auditing, 17(1), 75-99. https://doi.org/10.1111/j.10991123.2012.00458.x

Ali, S., \& Green, P. (2009). IT governance mechanisms in public sector organisations: An Australian context. Journal of Global Information Management (JGIM), 15(4), 41-63. https://doi.org/10.4018/jgim.2007100103

Arora, B., \& Rahman, Z. (2017). Investigating the influence of IT capability on sustainable competitive advantage (Bharat Arora).

Baker, D. A., \& Crompton, J. L. (2000). Quality, satisfaction and behavioral intentions. Annals of Tourism Research, 27(3), 785-804. https://doi.org/10.1016/S01607383(99)00108-5

Bandiyono, A., \& Muttaqin, A. H. H. (2020). Investigating the success of an E-Auction system initiatives among public servants: Validation of an integrated IS success model. 
IT governance and IT application orchestration capability role on organization performance during the COVID-19 pandemic: An intervening of business-IT alignment by Afrizal Tahar, Hafiez Sofyani,

Detra Putri Kunimasari

JEMA: Jurnal Ilmiah Bidang Akuntansi dan Manajemen, 17(2), 188-206. http://dx.doi.org/10.31106/jema.v17i1.5050

Barney, J. B. (2000). Firm reources ad sustained competitive advantege. Economics Meets Sociology in Strategic Management (Advances in Strategic Management), Vol. 17, 203227. https://doi.org/10.1016/S0742-3322(00)17018-4

Bharadwaj, A. S. (2000). A resource-based perspective on information technology capability and firm performance: an empirical investigation. MIS Quarterly, 24(1), 169-196.

Bianchi, I. S., Sousa, R. D., Pereira, R., \& Luciano, E. (2017). IT governance structures in Brazilian, Dutch and Portuguese universities. Procedia Computer Science, 121, 927933. https://doi.org/10.1016/j.procs.2017.11.120

Bobe, B. J., \& Kober, R. (2018). University dean personal characteristics and use of management control systems and performance measures. Studies in Higher Education, 45(2), 235-257. https://doi.org/10.1080/03075079.2018.1504911

Brammer, S., \& Clark, T. (2020). COVID-19 and management education: Reflections on challenges, opportunities, and potential futures. British Journal of Management, 31(3), 453-456. https://doi.org/10.1111/1467-8551.12425

Symons, C. (2005). IT governance framework: Structures, processes, and communication. Best Practices, Forrester Research Inc.

Chan, Y. E., \& Reich, B. H. (2007). IT alignment: What have we learned? Journal of Information Technology, 22(4), 297-315. https://doi.org/10.1057/palgrave.jit.2000109

Chang, S. J., Van Witteloostuijn, A., \& Eden, L. (2010). From the Editors: Common method variance in international business research. Journal of International Business Studies, 41(2), 178-184. https://doi.org/10.1057/jibs.2009.88

De Haes, S., \& Van Grembergen, W. (2009). An exploratory study into IT governance implementations and its impact on business/IT alignment. Information Systems Management, 26(2), 123-137. https://doi.org/10.1080/10580530902794786

De Haes, S., \& Van Grembergen, W. (2005). IT governance structures, processes and relational mechanisms: Achieving IT/business alignment in a major Belgian financial group. Proceedings of the Annual Hawaii International Conference on System Sciences, (May 2014), 237. https://doi.org/10.1109/hicss.2005.362

Dodd, T. (2020, July 6), The coronavirus has exposed the university rankings game. The Australian: Higher Education. https://www.theaustralian.com.au/highereducation/thecoronavirus-has-exposed-the-university-rankings-game/news- 
story/5b5cad62f7bca747c9dbfb4e4229

Fernández, A., \& Llorens, F. (2009). An IT governance framework for universities in Spain. EUNIS 2009 Conference, (August), 1-13.

Fowler Jr, F. J. (2013). Survey research methods. Washington DC: SAGE Publications, incorporated.

Gerow, J. E., Grover, V., Jason Bennett Thatcher, \& Roth, P. L. (2014). Looking toward the future of IT-business strategic alignment through the past: A meta-analysis. MIS Quarterly, 38(4), 1059-1085.

Gutierrez, A., Orozco, J., \& Serrano, A. (2009). Factors affecting IT and business alignment: a comparative study in SMEs and large organisations. Journal of Enterprise Information Management, 22(1), 197-211. https://doi.org/10.1108/17410390910932830

Hair, J. F., Sarstedt, M., Hopkins, L., \& Kuppelwieser, V. G. (2013). Partial least squares structural equation modeling (PLS-SEM): An emerging tool in business research. European Business Review, 26(2), 106-121. https://doi.org/10.1108/EBR-10-2013-0128

Hill, H., \& Wie, T. K. (2012). Indonesian universities in transition: Catching up and opening up. Bulletin of Indonesian Economic Studies, 48(2), 229-251. https://doi.org/10.1080/00074918.2012.694156

Kahli, R., \& Grover, V. (2008). Business value of IT: An essay on expanding research directions to keep up with the times. Journal of the Association for Information Systems. https://doi.org/10.17705/1jais.00147

Ketchen, D. J. (2013). A Primer on Partial Least Squares Structural Equation Modeling. Long Range Planning, 46(1-2), 184-185. https://doi.org/10.1016/j.lrp.2013.01.002

Kitsios, F. (2017). Strategic Change Management in Public Sector Transformation: The Case of Middle Manager Leadership in Greece This is the pre-final version. The final paper is available at: Kitsios , F . and M. Kamariotou ( 2017 ). Strategic Change Management in Publi. (November).

Krejcie, R. V., \& Morgan, D. W. (1970). Determining sample size for research activities. Educational and Psychological Measurement, 30(3), 607-610.

Kurniasih, N., Hasyim, C., Wulandari, A., Setiawan, M. I., \& Ahmar, A. S. (2018). Comparative case studies on Indonesian higher education rankings. In Journal of Physics: Conference Series (Vol. 954, No. 1, p. 012021). IOP Publishing.

Lazic, M. (2011). IT governance and business performance a resource based analysis. PACIS 2011 - 15th Pacific Asia Conference on Information Systems: Quality Research in Pacific. 
IT governance and IT application orchestration capability role on organization performance during the COVID-19 pandemic: An intervening of business-IT alignment by Afrizal Tahar, Hafiez Sofyani,

Detra Putri Kunimasari

Liang, T.-P., Chiu, Y.-C., Shelly P.J. Wu, \& Straub, D. (2011). The impact of IT governance on organizational performance. AMCIS 2011 Proceedings - All Submissions., 268.

Lunardi, G. L., Becker, J. L., Maçada, A. C. G., \& Dolci, P. C. (2014). The impact of adopting IT governance on financial performance: An empirical analysis among Brazilian firms. International Journal of Accounting Information Systems, 15(1), 66-81. https://doi.org/10.1016/j.accinf.2013.02.001

Means, B., Toyama, Y., Murphy, R., \& Baki, M. (2013). The effectiveness of online and blended learning: A meta-analysis of the empirical literature. Teachers College Record, 115(3), 1-47.

Mugge, R., \& Schoormans, J. P. L. (2012). Product design and apparent usability. The influence of novelty in product appearance. Applied Ergonomics, 43(6), 1081-1088. https://doi.org/10.1016/j.apergo.2012.03.009

Oehlhorn, C. E., Maier, C., Laumer, S., \& Weitzel, T. (2020). Human resource management and its impact on strategic business-IT alignment: A literature review and avenues for future research. The Journal of Strategic Information Systems, 101641. https://doi.org/10.1016/j.jsis.2020.101641

Oh, W., \& Pinsonneault, A. (2007). On the assessment of the strategic value of information technologies: conceptual and analytical approaches. MIS Quarterly, 31(2), 239-265. https://doi.org/10.2307/25148790

Papadopoulos, T., Gunasekaran, A., Dubey, R., \& Fosso Wamba, S. (2017). Big data and analytics in operations and supply chain management: managerial aspects and practical challenges. Production Planning \& Control, 28(11-12), 873-876. https://doi.org/10.1080/09537287.2017.1336795

Parker, L. D. (2020). Australian universities in a pandemic world: transforming a broken business model? Journal of Accounting \& Organizational Change, 16(4), 541-548. https://doi.org/10.1108/JAOC-07-2020-0086

Ping-Ju Wu, S., Straub, D. W., \& Liang, T.-P. (2015). How information technology governance mechanisms and strategic alignment influence organizational performance. MIS quarterly, 39(2), 497-518. https://doi.org/10.25300/MISQ/2015/39.2.10

Podsakoff, P. M., MacKenzie, S. B., Lee, J. Y., \& Podsakoff, N. P. (2003). Common method biases in behavioral research: A critical review of the literature and recommended remedies. Journal of Applied Psychology, 88(5), 879-903. https://doi.org/10.1037/00219010.88.5.879 
Primasari, C. H. (2020). Kematangan keselarasan strategis bisnis dan TI pada lembaga edukasi. Jurnal RESTI (Rekayasa Sistem Dan Teknologi Informasi), 1(10), 1-2.

Queiroz, M., Tallon, P. P., Sharma, R., \& Coltman, T. (2018). The role of IT application orchestration capability in improving agility and performance. Journal of Strategic Information Systems, 27(1), 4-21. https://doi.org/10.1016/j.jsis.2017.10.002

Rai, A., Pavlou, P. A., Im, G., \& Steve Du. (2012). Interfirm IT capability profiles and communications for cocreating relational value: Evidence from the logistics industry. Management Information Systems Quarterly, 36(1), 233-262.

Ray, G., Muhanna, W. A., \& Barney, J. B. (2014). Quarterly and the information technology of the customer performance a resource service process: Based analysis. Information Technology and the Performance of the Customer Service Process: A Resource-Based Analysis, 29(4), 625-652.

Reich, B. H., \& Benbasat, I. (2000). Factors that influence the social dimension of alignment between business and information technology objectives. MIS Quarterly: Management Information Systems, 24(1), 81-113. https://doi.org/10.2307/3250980

Sabherwal, R., \& Chan, Y. E. (2001). Alignment between Business and IS Strategies: A Study of Prospectors, Analyzers, and Defenders. Information Systems Research, 12(1), 11-33. https://doi.org/10.1287/isre.12.1.11.9714

Sambamurthy, V., \& Zmud, R. W. (2000). Research commentary: The organizing logic for an enterprise's IT activities in the digital era-A prognosis of practice and a call for research. Information Systems Research, 11(2), 105-114.

Seman, E. A. A., \& Salim, J. (2013). A model for business-IT alignment in Malaysian public universities. Procedia Technology, 11(Iceei), 1135-1141. https://doi.org/10.1016/j.protcy.2013.12.305

Setia, P., Venkatesh, V., \& Joglekar, S. (2013). Leveraging digital technologies: How information quality leads to localized capabilities and customer service performance. MIS Quarterly: Management Information Systems, 37(2), 565-590. https://doi.org/10.25300/MISQ/2013/37.2.11

Shenoy, V., Mahendra, S., \& Vijay, N. (2020). COVID 19 lockdown technology adaption, teaching, learning, students engagement and faculty experience. Mukt Shabd Journal, 9(4), 698-702.

Sirisomboonsuk, P., Gu, V. C., Cao, R. Q., \& Burns, J. R. (2018). Relationships between project governance and information technology governance and their impact on project performance. International Journal of Project Management, 36(2), 287-300. 
IT governance and IT application orchestration capability role on organization performance during the COVID-19 pandemic: An intervening of business-IT alignment by Afrizal Tahar, Hafiez Sofyani,

Detra Putri Kunimasari

https://doi.org/10.1016/j.ijproman.2017.10.003

Sofyani, H., Riyadh, H. A., \& Fahlevi, H. (2020). Improving service quality, accountability and transparency of local government: The intervening role of information technology governance. Cogent Business and Management, 7(1). https://doi.org/10.1080/23311975.2020.1735690

Tallon, P. P., Coltman, T., Queiroz, M., \& Sharma, R. (2016). Business process and information technology alignment: Construct conceptualization, empirical Illustration, and directions for future research. Journal of the Association for Information Systems, 17(9), 563-589. https://doi.org/10.17705/1jais.00438

Tallon, P. P., \& Pinsonneault, A. (2011). Competing perspectives on the link between strategic information technology alignment and organizational agility: Insights from a mediation model. MIS Quarterly: Management Information Systems, 35(2), 463-486. https://doi.org/10.2307/23044052

Tehseen, S., Ramayah, T., \& Sajilan, S. (2017). Testing and controlling for common method variance: A review of available methods. Journal of Management Sciences, 4(2), 142168. https://doi.org/10.20547/jms.2014.1704202

Turel, O., Liu, P., \& Bart, C. (2019). Is board IT governance a silver bullet? A capability complementarity and shaping view. International Journal of Accounting Information Systems, 33, 32-46. https://doi.org/10.1016/j.accinf.2019.03.002

Ullah, A., \& Lai, R. (2013). A systematic review of business and information technology alignment. ACM Transactions on Management Information Systems, 4(1). https://doi.org/10.1145/2445560.2445564

Ulum, I. (2019). Intellectual capital framework perguruan tinggi di Indonesia berdasarkan instrumen akreditasi program studi (IAPS) 4.0. Jurnal Reviu Akuntansi dan Keuangan, 9(3), 309-318. https://doi.org/10.22219/jrak.v9i3.10227

Wade, M., \& Hulland, J. (2004). Review: The resource-based view and information systems research: Review, extension, and suggestions for future research. MIS Quarterly: Management Information Systems, 28(1), 107-142. https://doi.org/10.2307/25148626

Weill, P., \& Ross, J. W. (2004). IT governance: how top performers manage IT decision rights for superior results. $269 . \quad$ Retrieved from http://books.google.com/books?id=xI5KdR21QTAC\&pgis $=1$ 